\title{
Effect of zinc and probiotics supplementation on performance and immune organs morphology in heat stressed broilers
}

\author{
M. Shah ${ }^{1,2}$, H. Zaneb ${ }^{2 \#}$, S. Masood ${ }^{2}$, I. Khan ${ }^{2}$, A. Sikandar ${ }^{3}$, S. Ashraf ${ }^{2}$, H.F. Rehman', \\ M.M. Usman ${ }^{2}$, F.A. Khan ${ }^{1}$, H. Amanullah ${ }^{1}$ \& H. Rehman ${ }^{4}$ \\ ${ }^{1}$ Department of Animal Health, The University of Agriculture, Peshawar 25120, Pakistan \\ ${ }^{2}$ Department of Anatomy and Histology, ${ }^{4}$ Department of Physiology, University of Veterinary and Animal Sciences, \\ Lahore 54000, Pakistan \\ ${ }^{3}$ Department of Pathobiology, Sub-campus Jhang, University of Veterinary and Animal Sciences, Lahore 35200, \\ Pakistan
}

(Received 22 January 2018; Accepted 16 July 2018; First published online 5 December 2018)

\begin{abstract}
Copyright resides with the authors in terms of the Creative Commons Attribution 4.0 South African License. See: http://creativecommons.org/licenses/by/4.0/za

Condition of use: The user may copy, distribute, transmit and adapt the work, but must recognize the authors and the South African Journal of Animal Science
\end{abstract}

\begin{abstract}
The dietary supplementation of trace minerals and probiotics has long been practiced to reduce the harmful effects of high environmental temperature in poultry. The study aimed to assess the effect of single or combined supplementation of $\mathrm{ZnSO}_{4} \cdot \mathrm{H}_{2} \mathrm{O}$ and probiotic (Protexin ${ }^{\circledR}$ ) on the growth performance, gut biometry and immune organs histomorphology in broilers reared under cyclic heat stress. For this purpose, 280 day-old broiler chicks were randomly divided into seven groups designated as control (basal diet), HS (heat stress + basal diet), $\mathrm{HS}-\mathrm{Zn} 30\left(\mathrm{HS}+30 \mathrm{mg} \mathrm{ZnSO}{ }_{4} \cdot \mathrm{H}_{2} \mathrm{O} / \mathrm{kg}\right.$ feed), $\mathrm{HS}-\mathrm{Zn} 60\left(\mathrm{HS}+60 \mathrm{mg} \mathrm{ZnSO}{ }_{4} \bullet \mathrm{H}_{2} \mathrm{O} / \mathrm{kg}\right.$ feed), HS-Pro (HS + $0.1 \mathrm{~g}$ Protexin $/ \mathrm{kg}$ feed), HS-Zn30-Pro (HS $+30 \mathrm{mg} \mathrm{ZnSO}{ }_{4} \bullet \mathrm{H}_{2} \mathrm{O} / \mathrm{kg}$ feed $+0.1 \mathrm{~g}$ Protexin ${ }^{\circledR} / \mathrm{kg}$ feed), and HS-Zn60-Pro (HS $+60 \mathrm{mg} \mathrm{ZnSO}{ }_{4} \cdot \mathrm{H}_{2} \mathrm{O} / \mathrm{kg}$ feed $+0.1 \mathrm{~g}$ Protexin $/ \mathrm{kg}$ feed). Each group consisted of five replicates (8 birds per replicate). The birds were fed on starter ( 0 - 21days) and grower (22 - 42 days) diets. From day 22 onwards, the birds were exposed to cyclic heat stress (temperature and relative humidity at $35 \pm 1{ }^{\circ} \mathrm{C}$ and $75 \pm 5 \%$ respectively) for 8 hours. The results revealed that birds exposed to heat stress showed significant decrease in body weight (BW) and increase in feed conversion ratio (FCR) compared to the control group. The dietary supplementation of $\mathrm{ZnSO}_{4} \bullet \mathrm{H}_{2} \mathrm{O}$ and probiotic either singly or in combination improved BW and FCR throughout the experimental period in heat-stressed broilers. Area of lymphatic nodule and lymphoid follicle in caecal tonsils and bursa of Fabricius increased in HS-Pro, HS-Zn30-Pro and HS-Zn60-Pro groups compared to HS group. In conclusion, zinc and probiotics combination partially improved performance and immune organs histomorphology in heat-stressed broilers.
\end{abstract}

Keywords: Chicken, heat stress, immune organ, morphology, Protexin

\#Corresponding author: hafsa.zaneb@uvas.edu.pk

\section{Introduction}

Heat is a significant stress factor in poultry production. Modern broilers are more exposed to heat stress owing to rapid growth and high metabolic activity (Khan et al., 2012; Chand et al., 2016). It has a negative impact on growth performance in terms of decrease in body weight (BW), feed intake (FI) and feed conversion ratio (FCR) in broiler (Khan et al., 2011). It causes high mortality due to free radical production leading to significant economic losses to the poultry industry (Zia ur Rahman et al., 2017).It has been reported that heat stress has negative impact on visceral organs including the pancreas (Kerr et al., 2003; Chand et al., 2017). Heat stress causes significant changes in gut morphology and intestinal microflora that decreases intestinal absorptive surface area in broiler chicken (Ashraf et al., 2013; Khan et al., 2014a; Sultan et al., 2018). High environmental temperature also causes decline of immune status in broilers (Bartlett \& Smith, 2003; Chand et al., 2014). Moreover, heat stress has been reported to influence the relative weight (RW) of immune organs such as the bursa of Fabricius, spleen and thymus due to decrease in number of lymphocytes and lymphoid follicle (Aengwanich, 2008). 
The dietary supplementation of trace minerals and probiotics has been practiced to reduce the unfavourable effects of high environmental temperature (Khan et al., 2014b; Shah et al., 2018). Among trace minerals, specific importance is assigned to zinc owing to its involvement in antioxidant defence system of the body ( $\mathrm{Naz}$ et al., 2016).It helps in the synthesis of metallothionein (cysteine rich protein) that helps in capturing free radicals produced during heat stress. The zinc requirement increases with an increase in environmental temperature (Siegel, 1995). Evidences have been accumulated that zinc increases FI, body weight gain (BWG) and improves FCR in heat-stressed birds (Chand et al., 2014). Zinc has an ameliorative effect on internal organs like heart, liver, gizzard, spleen and bursa of Fabricius in heat-stressed broilers (Cui et al., 2004).Probiotics are reported to have a complementary influence on performance and immunity of heat-stressed broilers (Khan \& Naz, 2013; Landy \& Kavyani, 2013). Protexin ${ }^{\circledR}$ (Probiotics International Ltd, UK) is a multi-strain probiotic containing bacterial strains of Lactobacillus plantarum, Lactobacillus acidophilus, Lactobacillus delbrueckii subsp. Bulgaricus, Bifidobacterium bifidum, Lactobacillus rhamnosus, Enterococcus faecium, Streptococcus salivarius subsp. Thermophilus and yeasts Aspergillus oryza and Candida pintolopesii (Khan et al., 2013).

A combination of zinc and probiotics augments host's intestinal health by enhancing the efficacy of probiotics (Bomba et al., 2002; Abudabos et al., 2017). It is therefore hypothesized that their dietary supplementation will positively influence the growth performance parameters and immunity of heat-stressed broilers. The present study thus aimed to determine the effect of single or combined supplementation of zinc and probiotics on the growth performance, gut biometry and immune organ histomorphology in broilers reared under cyclic heat stress.

\section{Materials and Methods}

The experiment was conducted on 280 healthy broiler chicks (Cobb 500) under standard management conditions in broiler experimental house, University of Veterinary and Animal Sciences, Lahore (Pakistan). The birds were individually weighed and randomly assigned to seven groups (Table 1). Each group consisted of five replicates ( 8 birds/replicate). Total duration of the experimental trial was 42 days. The study was approved by the Ethical Review Committee of the University (Notification No. DR/ 430 dated 16 August 2016). The temperature of $35 \pm 1{ }^{\circ} \mathrm{C}$ and relative humidity $(\mathrm{RH})$ of $65 \%$ were maintained by day- 1 of the experiment. Temperature was decreased gradually at the rate of $3{ }^{\circ} \mathrm{C}$ per week to $26{ }^{\circ} \mathrm{C}$ until day-21 of the experiment. From day 22 onwards, the temperature of $26{ }^{\circ} \mathrm{C}$ and $\mathrm{RH}$ of $65 \pm 5 \%$ were maintained for the control group. While for remaining heat-stressed groups the temperature and $\mathrm{RH}$ were maintained at $35 \pm$ $1{ }^{\circ} \mathrm{C}$ and $75 \pm 5 \%$ respectively from $9: 00$ to $17: 00$ (8 hours daily) followed by $26{ }^{\circ} \mathrm{C}$ and $65 \pm 5 \%$ RH for 16 hours for 3 weeks after 21 days of the experiment.

Table 1 Description of the experimental treatment

\begin{tabular}{|c|c|}
\hline Groups & Description \\
\hline Control & Basal diet \\
\hline HS & Heat stress + basal diet \\
\hline HS-Zn30 & $\mathrm{HS}+30 \mathrm{mg} \mathrm{ZnSO}{ }_{4} \cdot \mathrm{H}_{2} \mathrm{O} / \mathrm{kg}$ feed \\
\hline HS-Zn60 & $\mathrm{HS}+60 \mathrm{mg} \mathrm{ZnSO}{ }_{4} \bullet \mathrm{H}_{2} \mathrm{O} / \mathrm{kg}$ feed \\
\hline HS-Pro & $\mathrm{HS}+0.1 \mathrm{~g}$ Protexin ${ }^{\circledR} / \mathrm{kg}$ feed \\
\hline HS-Zn30-Pro & $\mathrm{HS}+30 \mathrm{mg} \mathrm{ZnSO}{ }_{4} \bullet \mathrm{H}_{2} \mathrm{O} / \mathrm{kg}$ feed $+0.1 \mathrm{~g}$ Protexin $^{\circledR} / \mathrm{kg}$ feed \\
\hline HS-Zn60-Pro & $\mathrm{HS}+60 \mathrm{mg} \mathrm{ZnSO}{ }_{4} \cdot \mathrm{H}_{2} \mathrm{O} / \mathrm{kg}$ feed $+0.1 \mathrm{~g}$ Protexin $^{\circledR} / \mathrm{kg}$ feed \\
\hline
\end{tabular}

The birds were fed a corn-based basal diet. The basal diet was formulated using NRC (1994) guidelines and its composition is presented in Table 2. Two phases of feed i.e. starter ( $1-21$ day) and grower (22 - 42 day) were adopted. Feed and water were provided ad libitum.

Proximate composition of feed samples were analyzed for nitrogen (Kjeldahl method; AOAC, 1990), crude protein $(\mathrm{N} \times 6.25)$, dry matter, crude fat $(A O A C, 1990)$ and crude fibre (AOAC, 2000). 
Table 2 Feed ingredients, composition and calculated AME of the starter and grower diets for broilers

\begin{tabular}{lcc}
\hline & Starter & Grower \\
\hline Feed ingredients (\%) & & \\
Corn & 40.15 & 57.57 \\
Rice broken & 15.0 & 0.00 \\
Rice polish & 0.00 & 4.00 \\
Wheat bran & 1.34 & 0.00 \\
Soya meal & 11.54 & 9.60 \\
Sunflower meal & 12.00 & 13.00 \\
Canola meal & 9.00 & 5.00 \\
Rapeseed meal & 5.00 & 7.60 \\
Guar meal & 1.00 & 0.00 \\
Molasses & 2.00 & 0.00 \\
Dicalcium phosphate & 1.73 & 1.96 \\
Premix* & 1.00 & 1.00 \\
Sodium chloride & 0.21 & 0.21 \\
Sodium bicarbonate & 0.03 & 0.065 \\
Proximate composition (\%) & & \\
Crude protein & 19.6 & 18.5 \\
Crude fat & 2.16 & 2.35 \\
Crude fibre & 1.26 & 1.80 \\
Total ash & 5.77 & 5.40 \\
Calculated AME (Kcal/kg) & 2750 & 2850
\end{tabular}

*Vitamin mineral premix (each kg contained): Ca, 195 g; K, 70 g; Na, 18 g; Mg, 6 g; Zn, 28.8 mg; Fe, 2000 mg; Cu, 400 mg; Mn, 1200 mg; Se, 8 mg; Co, 20 mg; I, 40 mg; vitamin A, 200000 IU; vitamin $\mathrm{D}_{3}, 80000 \mathrm{IU}$; vitamin E, $1072 \mathrm{IU}$; vitamin $\mathrm{K}_{3}, 34 \mathrm{mg}$; ascorbic acid, $1300 \mathrm{mg}$; thiamine, $35 \mathrm{mg}$; riboflavin, $135 \mathrm{mg}$; niacin, $1340 \mathrm{mg}$; vitamin $\mathrm{B}_{6}, 100 \mathrm{mg}$; folic acid, $34 \mathrm{mg}$; vitamin $\mathrm{B}_{12}, 670 \mu \mathrm{g}$; and biotin, $3350 \mu \mathrm{g}$

AME: apparent metabolizable energy

All the birds were weighed individually at the start of experiment and then on weekly intervals. The FI was recorded on daily basis and weekly feed intake per replicate was used to calculate FCR. The FI and FCR were calculated from average values of each replicate. The BW of control group was compared with that of the HS group while BW of supplemented groups was compared with HS group.

At day-42, two birds from each replicate (10 birds/group) were randomly selected and live BW was noted with the help of digital balance. The birds were killed by cervical dislocation and the visceral organs, i.e. proventriculus, gizzard, pancreas, spleen, small intestine, large intestine and bursa of Fabricius were collected and weighed. Filled as well as empty relative weights (RW) were noted. The length of small and large intestine was measured with the help of measuring tape (Khan et al., 2017).

For histological study the caecal tonsil and bursa of Fabricius were preserved in 10\% neutral buffered formalin solution. The tissues were then processed through paraffin embedding technique and microscopic sections $(5 \mu \mathrm{m})$ were prepared through rotary microtome (AMOS Scientific AEM-450, Australia). The microscopic sections were stained with haematoxylin and eosin stain (Bancroft et al., 2013). For morphometric analysis the tissue sections were observed with digital imaging analysis system (Prog Res ${ }^{\circledR}$ 2.1.1 Capture Prog Camera Control Software). In caecal tonsils the height, width, number and area of lymphatic nodules were measured from three non-serial microscopic sections (three lymphatic nodules per section) and their average was considered. The number of lymphatic nodules was counted per microscopic field. The area of lymphatic nodule was calculated using formula $(\mathrm{NL}) \times(\mathrm{NW})$, where $\mathrm{NL}$ is nodular height or length and NW is nodular width. In the bursa of Fabricius the height, width, total number and area of 
lymphatic follicle were measured from three microscopic sections (three lymphatic nodules per section). The area of lymphatic follicle was calculated using following formula $(F W) \times(F L)$, where $F W$ is follicular width and FL is follicular length (Khan et al., 2017).

The results obtained were presented as mean \pm SEM. To compare means one-way ANOVA was used through Statistical Package for Social Sciences, SPSS for Windows, version 20 (SPSS Inc., Chicago, IL, USA). The statistical differences among group means were determined through Tukey's post hock test and $P<0.05$ was considered significant.

\section{Results}

The effect of $\mathrm{ZnSO}_{4} \cdot \mathrm{H}_{2} \mathrm{O}$ and probiotic on BW is shown in Table 3. The BW was found similar $(P>0.05)$ in all groups at day 1 and 7 . At the end of week 3 , improved $(P<0.05)$ BW was observed in all supplemented groups compared to the control and HS groups. From day 22-42, the BW decreased $(P<0.05)$ in the HS group compared to the control group while it increased $(P<0.05)$ in all supplemented groups when compared with the HS group.

Table 3 Effect of $\mathrm{ZnSO}_{4} \bullet \mathrm{H}_{2} \mathrm{O}$ and probiotic supplementation on performance of broilers

\begin{tabular}{|c|c|c|c|c|c|c|c|c|c|}
\hline \multirow[b]{2}{*}{ Parameters } & \multicolumn{7}{|c|}{ Groups* } & \multirow[b]{2}{*}{ SEM } & \multirow[b]{2}{*}{$P$ - Value } \\
\hline & Control & HS & HS-Zn30 & HS-Zn60 & HS-Pro & $\begin{array}{c}\text { HS- } \\
\text { Zn30- } \\
\text { Pro }\end{array}$ & $\begin{array}{c}\text { HS- } \\
\text { Zn60- } \\
\text { Pro }\end{array}$ & & \\
\hline \multicolumn{10}{|c|}{ Body weight (g) } \\
\hline Day 1 & 36.04 & 34.35 & 39.33 & 41.00 & 37.34 & 38.63 & 34.47 & 0.83 & 0.25 \\
\hline Day 7 & 161.6 & 167.6 & 172.8 & 172.4 & 176.9 & 176.6 & 164.7 & 2.35 & 0.53 \\
\hline Day 21 & $805.7^{b}$ & $824.2^{\mathrm{b}}$ & $923.0^{\mathrm{a}}$ & $915.6^{\mathrm{a}}$ & $910.4^{\mathrm{a}}$ & $929.8^{\mathrm{a}}$ & $922.8^{\mathrm{a}}$ & 9.8 & $<0.01$ \\
\hline Day 42 & $2768.2^{\mathrm{a}}$ & $1945.6^{c}$ & $2382.2^{\mathrm{b}}$ & $2398.7^{\mathrm{b}}$ & $2373.5^{\mathrm{b}}$ & $2422.9^{b}$ & $2448.5^{\mathrm{b}}$ & 44.93 & $<0.01$ \\
\hline \multicolumn{10}{|c|}{ Feed conversion ratio (FCR) } \\
\hline Day 1-21 & $1.655^{\mathrm{a}}$ & $1.625^{\mathrm{a}}$ & $1.535^{\mathrm{a}}$ & $1.538^{\mathrm{a}}$ & $1.248^{\mathrm{b}}$ & $1.520^{\mathrm{a}}$ & $1.543^{\mathrm{a}}$ & 0.03 & $<0.01$ \\
\hline Day $22-42$ & $1.93^{\mathrm{c}}$ & $2.64^{\mathrm{a}}$ & $2.34^{\mathrm{b}}$ & $2.33^{b}$ & $2.33^{b}$ & $2.34^{b}$ & $2.28^{b}$ & 0.04 & $<0.01$ \\
\hline Total FCR & $1.80^{\mathrm{c}}$ & $2.16^{\mathrm{a}}$ & $1.99^{b}$ & $1.99^{b}$ & $1.93^{\mathrm{bc}}$ & $1.98^{\mathrm{b}}$ & $1.95^{\mathrm{b}}$ & 0.02 & $<0.01$ \\
\hline
\end{tabular}

${ }^{\mathrm{abc}}$ means in a row with different superscripts are significantly different at $P<0.05$

${ }^{*}$ Control (basal diet), HS (heat stress + basal diet), HS-Zn30 (HS + $30 \mathrm{mg} \mathrm{ZnSO}{ }_{4} \bullet \mathrm{H}_{2} \mathrm{O} / \mathrm{kg}$ feed), $\mathrm{HS}-\mathrm{Zn} 60(\mathrm{HS}+60 \mathrm{mg}$

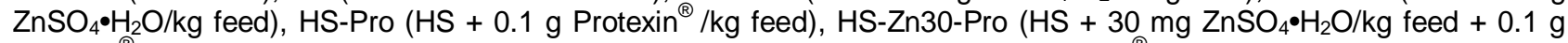

Protexin $^{\circledR} / \mathrm{kg}$ feed) and HS-Zn60-Pro $\left(\mathrm{HS}+60 \mathrm{mg} \mathrm{ZnSO}{ }_{4} \cdot \mathrm{H}_{2} \mathrm{O} / \mathrm{kg}\right.$ feed $+0.1 \mathrm{~g}$ Protexin ${ }^{\circledR} / \mathrm{kg}$ feed $)$

The effect of $\mathrm{ZnSO}_{4} \cdot \mathrm{H}_{2} \mathrm{O}$ and probiotic on FCR is presented in Table 3 . The results revealed that among supplemented groups HS-Pro had better $(P<0.05)$ FCR compared to HS group for starter period (days 1 - 21). Higher $(P<0.05)$ FCR was observed in HS group when compared to control group while improved $(P<0.05)$ FCR was observed in all supplemented groups when compared to HS group in last three weeks (days 22 - 42) of the experiment. However, the total FCR was found to be better $(P<0.05)$ in HS-Pro group among all supplemented groups when compared to HS group.

There was no effect of $\mathrm{ZnSO}_{4} \bullet \mathrm{H}_{2} \mathrm{O}$ and probiotic individually or in combination on filled and empty relative weights of the proventriculus, gizzard, ceca and length of small and large intestine (Table 4). The RW of pancreas and bursa of Fabricius decreased $(P<0.05)$ in the HS group compared to the control group but was higher $(P<0.05)$ in all supplemented groups when compared to the HS group. The RW of spleen was higher $(P<0.05)$ in HS-Zn60, HS-Pro, HS-Zn30-Pro and HS-Zn60-Pro than the HS group. The empty RW of small intestine decreased $(P<0.05)$ in the HS group when compared to the control group; however, it increased $(P<0.05)$ in the HS-Zn60, HS-Pro, HS-Zn30-Pro and HS-Zn60-Pro groups compared to the HS group.

In caecal tonsils, the area of lymphatic nodules (ALN) was greater $(P<0.05)$ in HS-Pro, HS-Zn30-Pro and HS-Zn60-Pro groups than the HS group (Table 5). In the bursa of Fabricius, the length (LLF) and area (ALF) of lymphoid follicles was higher $(P<0.05)$ in the HS-Zn60, HS-Zn30-Pro and HS-Zn60-Pro than in the HS group (Table 6). The number of lymphoid follicle (NLF) decreased $(P<0.05)$ in the HS-Zn60-Pro group when compared to the HS group, HS-Zn60-Pro. 
Table 4 Effect of $\mathrm{ZnSO}_{4} \bullet \mathrm{H}_{2} \mathrm{O}$ and probiotic on visceral organs of broiler

\begin{tabular}{|c|c|c|c|c|c|c|c|c|c|}
\hline \multirow[b]{2}{*}{ Organ } & \multicolumn{7}{|c|}{ Groups } & \multirow[b]{2}{*}{ SEM } & \multirow[b]{2}{*}{$P$-value } \\
\hline & Control & HS & HS-Zn30 & HS-Zn60 & $\begin{array}{l}\text { HS- } \\
\text { Pro. }\end{array}$ & $\begin{array}{c}\text { HS-Zn30- } \\
\text { Pro }\end{array}$ & $\begin{array}{l}\text { HS-Zn60- } \\
\text { Pro }\end{array}$ & & \\
\hline Prov F (\%) & 0.34 & 0.35 & 0.38 & 0.42 & 0.41 & 0.38 & 0.40 & 0.01 & 0.14 \\
\hline Prov E (\%) & 0.32 & 0.34 & 0.35 & 0.37 & 0.39 & 0.36 & 0.38 & 0.01 & 0.27 \\
\hline Giz F (\%) & 2.19 & 2.41 & 2.20 & 2.39 & 2.21 & 2.14 & 2.50 & 0.04 & 0.13 \\
\hline Giz E (\%) & 1.78 & 1.75 & 1.68 & 1.79 & 1.77 & 1.69 & 1.97 & 0.03 & 0.07 \\
\hline Pancreas (\%) & $0.221^{\mathrm{a}}$ & $0.139^{b}$ & $0.202^{\mathrm{a}}$ & $0.210^{\mathrm{a}}$ & $0.205^{\mathrm{a}}$ & $0.200^{\mathrm{a}}$ & $0.209^{a}$ & 0.01 & $<0.01$ \\
\hline Spleen (\%) & $0.108^{\mathrm{a}}$ & $0.041^{b}$ & $0.085^{b}$ & $0.099^{\mathrm{a}}$ & $0.092^{\mathrm{a}}$ & $0.101^{a}$ & $0.111^{\mathrm{a}}$ & 0.01 & $<0.01$ \\
\hline $\mathrm{BF}(\%)$ & $0.15^{\mathrm{a}}$ & $0.06^{\mathrm{b}}$ & $0.12^{\mathrm{a}}$ & $0.13^{\mathrm{a}}$ & $0.14^{\mathrm{a}}$ & $0.14^{\mathrm{a}}$ & $0.15^{\mathrm{a}}$ & 0.01 & $<0.01$ \\
\hline SI F (\%) & $2.80^{\mathrm{ab}}$ & $2.49^{a b}$ & $2.59^{\mathrm{ab}}$ & $3.04^{a}$ & $2.34^{\mathrm{b}}$ & $2.32^{\mathrm{b}}$ & $2.39^{b}$ & 0.07 & $<0.01$ \\
\hline SI E (\%) & $2.29^{\mathrm{a}}$ & $1.78^{\mathrm{b}}$ & $1.96^{\mathrm{ab}}$ & $2.25^{\mathrm{a}}$ & $2.12^{\mathrm{a}}$ & $2.21^{\mathrm{a}}$ & $2.26^{a}$ & 0.04 & $<0.01$ \\
\hline Ceca F (\%) & 0.47 & 0.35 & 0.36 & 0.42 & 0.42 & 0.44 & 0.45 & 0.01 & 0.08 \\
\hline Ceca E (\%) & 0.32 & 0.25 & 0.27 & 0.28 & 0.29 & 0.30 & 0.32 & 0.01 & 0.09 \\
\hline LSI (cm) & 159.0 & 140.7 & 143.9 & 147.1 & 146.1 & 149.7 & 151.8 & 1.81 & 0.16 \\
\hline LLI (cm) & 41.40 & 35.44 & 36.60 & 38.80 & 36.70 & 38.70 & 39.20 & 0.58 & 0.11 \\
\hline
\end{tabular}

The foot note is same as for Table 3

Prov, Proventriculus; Giz, Gizzard; BF, bursa of Fabricius; SI, small intestine; LSI, length of small intestine; LLI, length of large intestine; F, filled; E, empty. Control (basal diet), $\mathrm{HS}$ (heat stress + basal diet), $\mathrm{HS}-\mathrm{Zn30}\left(\mathrm{HS}+30 \mathrm{mg} \mathrm{ZnSO}_{4} \bullet \mathrm{H}_{2} \mathrm{O}\right.$ $/ \mathrm{kg}$ feed), HS-Zn60 (HS $+60 \mathrm{mg} \mathrm{ZnSO}{ }_{4} \bullet \mathrm{H}_{2} \mathrm{O} / \mathrm{kg}$ feed), HS-Pro (HS $+0.1 \mathrm{~g}$ Protexin ${ }^{\circledR} / \mathrm{kg}$ feed), HS-Zn30-Pro (HS +30 $\mathrm{mg} \mathrm{ZnSO}_{4} \bullet \mathrm{H}_{2} \mathrm{O} / \mathrm{kg}$ feed $+0.1 \mathrm{~g}$ Protexin $^{\circledR} / \mathrm{kg}$ feed) and HS-Zn60-Pro (HS $+60 \mathrm{mg} \mathrm{ZnSO}{ }_{4} \bullet \mathrm{H}_{2} \mathrm{O} / \mathrm{kg}$ feed $+0.1 \mathrm{~g}$ Protexin ${ }^{\circledR}$ $/ \mathrm{kg}$ feed)

Table 5 Effect of $\mathrm{ZnSO}_{4} \bullet \mathrm{H}_{2} \mathrm{O}$ and probiotic on caecal tonsils histomorphology of broiler

\begin{tabular}{|c|c|c|c|c|c|c|c|c|c|}
\hline \multirow[b]{2}{*}{ Parameters } & \multicolumn{7}{|c|}{ Groups } & \multirow[b]{2}{*}{ SEM } & \multirow{2}{*}{$\begin{array}{c}P \text { - } \\
\text { value }\end{array}$} \\
\hline & Control & HS & $\begin{array}{c}\text { HS- } \\
\text { Zn30 }\end{array}$ & $\begin{array}{l}\text { HS- } \\
\text { Zn60 }\end{array}$ & HS-Pro & $\begin{array}{l}\text { HS-Zn30- } \\
\text { Pro }\end{array}$ & $\begin{array}{l}\text { HS-Zn60- } \\
\text { Pro }\end{array}$ & & \\
\hline LLN $(\mu \mathrm{m})$ & $121.14^{\mathrm{a}}$ & $92.15^{d}$ & $97.46^{\mathrm{cd}}$ & $98.26^{\mathrm{bcd}}$ & $113.86^{\mathrm{abc}}$ & $119.7^{\mathrm{a}}$ & $119.34^{\mathrm{ab}}$ & 2.25 & $<0.01$ \\
\hline $\mathrm{WLN}(\mu \mathrm{m})$ & $81.90^{\mathrm{a}}$ & $42.85^{\mathrm{c}}$ & $47.73^{\mathrm{bc}}$ & $49.49^{\mathrm{bc}}$ & $52.73^{\mathrm{bc}}$ & $54.89^{\mathrm{bc}}$ & $60.56^{\mathrm{b}}$ & 1.86 & $<0.01$ \\
\hline $\operatorname{ALN}\left(\mu \mathrm{m}^{2}\right)$ & $9894.5^{\mathrm{a}}$ & $3903.7^{d}$ & $4754.6^{\mathrm{cd}}$ & $4814.3^{\mathrm{cd}}$ & $5976.1^{\mathrm{bc}}$ & $6543.2^{\mathrm{bc}}$ & $7213.1^{\mathrm{b}}$ & 271.45 & $<0.01$ \\
\hline NLN & $2.90^{\mathrm{b}}$ & $5.00^{\mathrm{ab}}$ & $4.20^{\mathrm{ab}}$ & $5.30^{\mathrm{ab}}$ & $4.90^{\mathrm{ab}}$ & $7.20^{\mathrm{a}}$ & $6.40^{\mathrm{ab}}$ & 0.38 & 0.04 \\
\hline
\end{tabular}

The foot note is same as for Table 3

LLN: length of lymphatic nodule; WLN: width of lymphatic nodule; ALN: area of lymphatic nodule; NLN: number of lymphatic nodules

${ }^{\star}$ Control (basal diet), HS (heat stress + basal diet), HS-Zn30 (HS + $30 \mathrm{mg} \mathrm{ZnSO}{ }_{4} \bullet \mathrm{H}_{2} \mathrm{O} / \mathrm{kg}$ feed), HS-Zn60 (HS + $60 \mathrm{mg}$

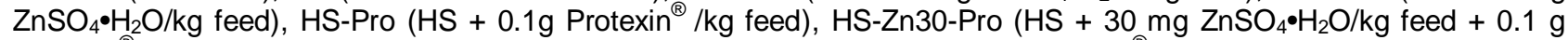
Protexin $^{\circledR} / \mathrm{kg}$ feed) and HS-Zn60-Pro (HS $+60 \mathrm{mg} \mathrm{ZnSO}{ }_{4} \cdot \mathrm{H}_{2} \mathrm{O} / \mathrm{kg}$ feed $+0.1 \mathrm{~g}$ Protexin ${ }^{\circledR} / \mathrm{kg}$ feed) 
Table 6 Effect of $\mathrm{ZnSO}_{4} \bullet \mathrm{H}_{2} \mathrm{O}$ and probiotic on bursa of Fabricius histomorphology of broiler

\begin{tabular}{lccccccccc}
\hline \multirow{2}{*}{ Parameters } & Control & HS & $\begin{array}{c}\text { HS- } \\
\text { Zn30 }\end{array}$ & $\begin{array}{c}\text { HS- } \\
\text { Zn60 }\end{array}$ & HS-Pro & $\begin{array}{c}\text { HS- } \\
\text { Zn3- } \\
\text { Pro }\end{array}$ & $\begin{array}{c}\text { HS- } \\
\text { Zn60- } \\
\text { Pro }\end{array}$ & SEM & P-value \\
\hline LLF $(\mathrm{mm})$ & $0.46^{\mathrm{a}}$ & $0.25^{\mathrm{d}}$ & $0.26^{\mathrm{d}}$ & $0.36^{\mathrm{bc}}$ & $0.28^{\mathrm{cd}}$ & $0.39^{\mathrm{ab}}$ & $0.40^{\mathrm{ab}}$ & 0.01 & $<0.01$ \\
WLF $(\mathrm{mm})$ & $0.23^{\mathrm{a}}$ & $0.14^{\mathrm{d}}$ & $0.15^{\mathrm{cd}}$ & $0.18^{\mathrm{bc}}$ & $0.18^{\mathrm{bc}}$ & $0.19^{\mathrm{b}}$ & $0.22^{\mathrm{ab}}$ & 0.00 & $<0.01$ \\
ALF $\left(\mathrm{mm}^{2}\right)$ & $0.10^{\mathrm{a}}$ & $0.04^{\mathrm{d}}$ & $0.04^{\mathrm{d}}$ & $0.07^{\mathrm{bc}}$ & $0.05^{\mathrm{cd}}$ & $0.08^{\mathrm{b}}$ & $0.09^{\mathrm{ab}}$ & 0.00 & $<0.01$ \\
NLF & $12.0^{\mathrm{b}}$ & $19.3^{\mathrm{a}}$ & $17.1^{\mathrm{ab}}$ & $15.5^{\mathrm{ab}}$ & $15.6^{\mathrm{ab}}$ & $14.3^{\mathrm{ab}}$ & $12.2^{\mathrm{b}}$ & 0.57 & $<0.01$ \\
\hline
\end{tabular}

The foot note is same as for Table 3

LLF: length of lymphatic follicle; WLF: width of lymphatic follicle; ALF: area of lymphatic follicle; NLF: number of lymphatic follicle

Control (basal diet), $\mathrm{HS}$ (heat stress + basal diet), $\mathrm{HS}-\mathrm{Zn} 30\left(\mathrm{HS}+30 \mathrm{mg} \mathrm{ZnSO}{ }_{4} \bullet \mathrm{H}_{2} \mathrm{O} / \mathrm{kg}\right.$ feed), $\mathrm{HS}-\mathrm{Zn} 60(\mathrm{HS}+60 \mathrm{mg}$ $\mathrm{ZnSO}_{4} \cdot \mathrm{H}_{2} \mathrm{O} / \mathrm{kg}$ feed), HS-Pro (HS $+0.1 \mathrm{~g}$ Protexin ${ }^{\circledR} / \mathrm{kg}$ feed), $\mathrm{HS}-\mathrm{Zn} 30-P r o\left(\mathrm{HS}+30 \mathrm{mg} \mathrm{ZnSO}{ }_{4} \cdot \mathrm{H}_{2} \mathrm{O} / \mathrm{kg}\right.$ feed $+0.1 \mathrm{~g}$ Protexin $^{\otimes} / \mathrm{kg}$ feed) and $\mathrm{HS}-\mathrm{Zn} 60-$ Pro $\left(\mathrm{HS}+60 \mathrm{mg} \mathrm{ZnSO}{ }_{4} \cdot \mathrm{H}_{2} \mathrm{O} / \mathrm{kg}\right.$ feed $+0.1 \mathrm{~g}$ Protexin $/ \mathrm{kg}$ feed)

\section{Discussion}

Heat stress is known to adversely affect broiler performance. Zinc and probiotic supplementation play an important role in ameliorating the harmful effects of heat stress in broilers. The results of current study revealed that no improvement in BW of all supplemented groups was observed in first week of the experiment when compared to control and HS groups. The results regarding BW in current study were similar to that of Yang et al. (2011) and Swain (2012). They reported no improvement in BW with dietary supplementation of zinc and probiotic in broilers in the first week. This may be due to late establishment of gut microflora to show any favourable effects in probiotic supplemented groups including HS-Pro, HS-Zn30Pro and HS-Zn60-Pro groups (Swain, 2012). Higher BW was found in all supplemented groups compared to the control and HS groups on day 21.The improved BW in the HS-Zn30 and HS-Zn60 groups may be linked to $\mathrm{ZnSO}_{4} \cdot \mathrm{H}_{2} \mathrm{O}$ supplementation that plays an important role in enhancing activity of trypsin in pancreas and digestive enzymes including lipase, amylase, trypsin and chymotrypsin at intestinal level, as reported in earlier study (Hu et al., 2013). The higher BW in HS-Pro group can be attributed to supplementation of the probiotic. The probiotics help in the establishment of beneficial gut microflora resulting in lower levels of pathogenic bacteria and better nutrients absorption due to modulation of intestinal surface area (Brzoska et al., 1999; Ashraf et al., 2013). The final BW decreased in HS group when compared with control group. However, it increased in all supplemented groups when compared with the HS group. The decreased BW in the HS group may be linked to decreased digestibility of nutrients due to lack of digestive enzymes including amylase, chymotrypsin and trypsin due to heat stress. The increased BW in HS-Zn30 and HS-Zn60 groups can be attributed to $\mathrm{ZnSO}_{4} \cdot \mathrm{H}_{2} \mathrm{O}$ through reversal of the negative effects of oxidative damage in the pancreas (Onderci et al., 2003). The increased BW in the HS- Pro, HS-Zn30-Pro and HS-Zn60-Pro treatments may be attributed to the supplementation of the probiotic. Probiotics have been documented to increase villus height, villus height to the crypt depth ratio that results in increased surface area for absorption in the intestine (Ashraf et al., 2013).

Improved FCR was observed in the HS-Pro group compared to all other groups in the starter phase (days 1 - 21). This improvement in the HS-Pro group may be associated with dietary supplementation of probiotic that increased beneficial intestinal microflora and resulted in better feed utilization (Edens, 2003). A higher FCR was observed in the HS group compared to the control group in finisher phase (days 22 - 42). The higher FCR in the HS group may be associated with a reduced feed digestibility of feed that lead to an increased FCR. The improved (lower) FCR was found in all supplemented groups compared to the HS group. The decreased FCR in HS-Zn30, HS-Zn60 and HS-Zn60-Pro groups may be linked to $\mathrm{ZnSO}_{4} \bullet \mathrm{H}_{2} \mathrm{O}$ which might have ameliorated the negative effects of heat stress, and effectuated a better FCR. The improved FCR in HS-Pro group might be attributed to multiple factors such as improvement in digestion, metabolism of nutrients and minerals, decrease in intestinal $\mathrm{pH}$ through production of organic and volatile fatty acids and increase in amylase enzymes activity (Jin et al., 2000; Dhama \& Singh, 2010). All these factors help in better utilization of feed within the small intestine. In the present study decreased RW of the pancreas was observed in the HS group compared to the control group. These results are comparable to an 
earlier study (Kerr et al., 2003), which reported decreased weight of the pancreas with environmental temperature of $33{ }^{\circ} \mathrm{C}$ in pigs. The decreased weight is proposed to have resulted from pancreatic tissue damage through oxidative stress. The relative weight of the pancreas improved in all supplemented groups (HS-Zn30, HS-Zn60, HS-Pro, HS-Zn30-Pro and HS-Zn60-Pro) compared to the HS group. The increased relative weight of pancreas in zinc-supplemented groups may be related to lowered oxidative stress in pancreatic tissue because of the antioxidant role of zinc (Sahin \& Kucuk, 2003). The results about increase in RW of the pancreas with probiotic supplementation endorse the results of Samli et al. (2007). The mechanism behind increased relative weight of the pancreas in combined zinc and probiotics supplemented groups (HS-Zn30-Pro and HS-Zn60-Pro) is unclear and needs further investigation. The RW of the spleen and bursa of Fabricius were lower in the HS group compared to the control group, but increased in the HSZn60, HS-Pro, HS-Zn30-Pro and HS-Zn60-Pro groups. The decreased relative weight of immune organs in the HS group may be associated with heat stress-induced zinc deficiency that results in atrophy of lymphoid tissue. The results about increased relative weights of the immune organs in supplemented groups can be linked with increased area of lymphoid follicles due to increased lymphocytic concentration to these organs (Akbari et al., 2008) The relative empty weight of the small intestine was lower in the HS group compared to control group, but increased in the HS-Zn60, HS-Pro, HS-Zn30-Proand HS-Zn60-Pro groups when compared with HS group. The decreased intestinal weight in the HS group may be related to decreased villus surface area in the small intestine and reduced level of thyroxin. Thyroxine level is reduced due to increased level of cortisol during heat stress (Ganong, 2005) that has an enterotropic effect (Ashraf et al., 2013). The increased intestinal weight in supplemented groups (HS-Zn60, HS-Pro, HS-Zn30-Pro, and HSZn60-Pro) may be related to zinc through reversal of unfavourable effects of heat stress and enhancement of enterocytes proliferation (MacDonald, 2000).

In the caecal tonsils, the length, width and area of lymphatic nodules decreased in HS group. These findings about caecal tonsils were similar to findings of previous study (Liu et al., 2012) which revealed decreased caecal tonsil weight with dietary flourine-induced oxidative stress. In the present study, the lowered LLN, WLN and ALN may be due to reduced concentration of lymphocytes resulting from heat stress as the heat stress is reported to decrease circulating lymphocyte percentage (Altan et al., 2003). Dietary supplementation of probiotic or its combination with $\mathrm{ZnSO}_{4} \bullet \mathrm{H}_{2} \mathrm{O}$ increased the LLN and ALN in caecal tonsils. The increased LLN and ALN may be due to increased number of lymphocytes as probiotics and zinc both have been reported to increase lymphocyte concentration (Rahimi \& Khaksefidi, 2006; Rouhalamini et al., 2014).

In bursa of Fabricius the LLF, ALF and NLF decreased in HS group. The decreased LLF and ALF may be the result of reduction in lymphocytic concentration as reported in an earlier study (Aengwanich, 2008). The enhanced adrenal activity due to heat stress results in release of corticosteroids that consequently cause suppression of cell proliferation factor (Siegel, 1995). The LLF and ALF increased with dietary supplementation of $\mathrm{ZnSO}_{4} \bullet \mathrm{H}_{2} \mathrm{O}$ and probiotic either alone or in combination. It is known that zinc has a role in lymphocyte proliferation or lymphokines secretion (Naz et al., 2016), but further studies are needed to suggest possible mechanisms behind observations made in groups supplemented with combined $\mathrm{ZnSO}_{4} \cdot \mathrm{H}_{2} \mathrm{O}$ and probiotic. However, both $\mathrm{ZnSO}_{4} \bullet \mathrm{H}_{2} \mathrm{O}$ and probiotic alone are known to increase lymphocytic concentration.

\section{Conclusion}

Heat stress negatively impacted the performance parameters as well as relative weights and histomorphology of immune organs, while, supplementation of $\mathrm{ZnSO}_{4} \bullet \mathrm{H}_{2} \mathrm{O}$ and a probiotic either alone or in combination, partially ameliorated the negative effects of heat stress and improved the afore-mentioned parameters.

\section{Acknowledgements}

The author acknowledges the Department of Poultry Production, University of Veterinary and Animal Sciences Lahore, for provision of broiler experimental house for smooth running of experimental trial.

\section{Authors' Contributions}

MS, HZ, SM, HFR and HR, contributed in experimental design, data analysis and manuscript writing. MS, HZ, SM, IK, AS, SA and MMU contributed in sample processing, data acquisition and interpretation. HA and FAK contributed in manuscript preparation.

\section{Conflict of Interest Declaration}

The authors declared no conflict of interest. 


\section{References}

Abudabos, A.M., Alyemni, A.H., Dafalla, Y.M. \& Khan, R.U., 2017. Effect of organic acid blend and Bacillus subtilis alone or in combination on growth traits, blood biochemical and antioxidant status in broiler exposed to Salmonella typhimurium challenge during the starter phase. J. Appl. Anim. Res. 45, 538-542.

Aengwanich, W., 2008. Pathological changes and effect of ascorbic acid on lesion scores of bursa of Fabricius in broilers under chronic heat stress. Res. J. Vet. Sci. 1, 62-66.

Akbari, M., Kermanshahi, H., Moghaddam, H.N., Moussavi, A.H. \& Afshari, J.T., 2008. Effects of wheat soybean meal based diet supplementation with vitamin A, vitamin $E$ and zinc on blood cells, organ weights and humoral immune response in broiler chickens. J. Anim. Vet. Adv. 7, 297-304.

Altan, O., Pabuçcuoglu, A., Altan, A., Konyalioglu, S. \& Bayraktar, H., 2003. Effect of heat stress on oxidative stress, lipid peroxidation and some stress parameters in broilers. Br. Poult. Sci. 44, 545-550.

Ashraf, S., Zaneb, H., Yousaf, M., Ijaz, A., Sohail, M., Muti, S., Usman, M., Ijaz, S. \& Rehman, H., 2013. Effect of dietary supplementation of prebiotics and probiotics on intestinal microarchitecture in broilers reared under cyclic heat stress. J. Anim. Phys. Anim. Nutr. 97, 68-73.

AOAC, 1990. Offcial methods of analysis, 15th ed. Association of Official Analytical Chemists, Washington, DC., USA.

AOAC, 2000. Official methods of analysis.17th Ed., International, Gaithersburg, MD, Official Method 920.39.

Bancroft, J.D., Floyd, A.D. \& Suvarna, S.K., 2013. Bancroft's Theory and Practice of Histological Techniques. (7th ed.), Elsevier Health Science, New York, NY., USA.

Bartlett, J.R. \& Smith, M.O., 2003. Effects of different levels of zinc on the performance and immunocompetence of broilers under heat stress. Poult. Sci. 82, 1580-1588.

Bomba, A., Nemcova, Rr., Mudronova, D. \& Guba, P., 2002. The possibilities of potentiating the efficacy of probiotics. Trends Food Sci. Technol. 13, 121-126.

Brzoska, F., Grzybowski, R., Stecka, K. \& Pieszka, M., 1999. Nutritive efficiency of selected probiotic microorganisms in chicken broilers. Ann. Anim. Sci. 26, 291-301.

Chand, N., Naz, S., Khan, A., Khan, S. \& Khan, R.U., 2014. Performance traits and immune response of broiler chicks treated with zinc and ascorbic acid supplementation during cyclic heat stress. Int. J. Biometeorol. 58, 2153-2157.

Chand, N., Muhammad, S., Khan, R.U., Alhidary, I.A. \& Zia ur Rahman., 2016. Ameliorative effect of synthetic $\mathrm{Y}$-aminobutyric acid (GABA) on performance traits, antioxidant status and immune response in broiler exposed to cyclic heat stress. Environ. Sci. Poll. Res. 23, 23930-23935.

Chand, N., Naz, S., Maris, H., Khan, R.U., Khan, S. \& Qureshi, M.S., 2017. Effect of betaine supplementation on the performance and immune response of heat stressed broilers. Pak. J. Zool. 49, 1857-1862.

Cui, H., Xi, P., Junliang, D., Debing, L. \& Guang, Y., 2004. Pathology of lymphoid organs in chickens fed a diet deficient in zinc. Avian Pathol. 33, 519-524.

Dhama, K. \& Singh, S.D., 2010. Probiotics improving poultry health and production: an overview. Poult. Punch. 26, 41-41.

Edens, F., 2003. An alternative for antibiotic se in poultry: probiotics. Braz. J. Poult. Sci. 5, 75-97.

Ganong, W.F., 2005. The Thyroid Gland. In: Review of Medical Physiology. (22 ${ }^{\text {nd }}$ ed.). McGraw-Hill, Singapore.

Hu, C., Qian, Z., Song, J., Luan, Z. \& Zuo, A., 2013. Effects of zinc oxide-montmorillonite hybrid on growth performance, intestinal structure, and function of broiler chicken. Poult. Sci. 92, 143-150.

Jin, L., Ho, Y., Abdullah, N. \& Jalaludin, S., 2000. Digestive and bacterial enzyme activities in broilers fed diets supplemented with Lactobacillus cultures. Poult. Sci. 79, 886-891.

Kerr, B., Yen, J., Nienaber, J. \& Easter, R., 2003. Influences of dietary protein level, amino acid supplementation and environmental temperature on performance, body composition, organ weights and total heat production of growing pigs. J. Anim. Sci. 81, 1998-2007.

Khan, I., Zaneb, H., Masood, S., Yousaf, M., Rehman, H. \& Rehman, H., 2017. Effect of Moringa oleifera leaf powder supplementation on growth performance and intestinal morphology in broiler chickens. J. Anim. Phys. Anim. Nutr.101, 114-121.

Khan, R.U. \& Naz, S., 2013. Application of probiotics in poultry production. Wrld's Poult. Sci. J. 69, $621-632$.

Khan, R.U., Naz, S., Nikousefat, Z., Tufarelli, V., Javadani, M., Rana, N. \& Laudadio, V., 2011. Effect of vitamin E in heat-stressed poultry. Wrld's Poult. Sci. J. 67, 469-478.

Khan, R.U., Naz, S., Nikousefat, Z., Selvaggi, M., Laudadio, V. \& Tufarelli, V., 2012. Effect of ascorbic acid in heatstressed poultry. Wrld's Poult. Sci. J. 68, 477-490.

Khan, R.U., Rahman, Z.U., Javed, I. \& Muhammad, F., 2013. Supplementation of vitamins, probioitics and proteins on oxidative stress, enzymes and hormones in post-moulted male broiler breeder. ArchivTierzucht. 61, 607-616.

Khan, R.U., Rahman, Z.U., Javed, I. \& Muhammad, F., 2014a. Serum antioxidants and trace minerals as influenced by vitamins, protein and probiotics in male broiler breeders. J. Appl. Anim. Res. 42, 249-255.

Khan, R.U., Naz, S. \& Dhama, K., 2014b. Chromium: pharmacological applications in heat stressed poultry. Int. J. Pharmacol. 10, 213-317.

Landy, N. \& Kavyani, A., 2013. Effects of using a multi strain probiotic on performance, immune responses and cecal microflora composition in broiler chickens reared under cyclic heat stress condition. Iran J. Appl. Anim. Sci. 3, 703-708.

Liu, J., Cui, H., Peng, X., Fang, J., Zuo, Z., Wang, H., Wu, B., Deng, Y. \& Wang, K., 2012. High dietary fluorine induction of oxidative damage in the cecal tonsil of broilers. Fluoride $45,47$.

MacDonald, R.S., 2000. The role of zinc in growth and cell proliferation. J. Nutr. 130, 1500S-1508S.

NRC, 1994. Nutrient Requirements of Poultry $\left(9^{\text {th }}\right.$ ed.). National Academy Press, Washington, D.C., USA. 
Naz, S., Idris, M., Khalique, M.A., Zia-ur-Rahman, Alhidary, I.A., Abdelrahman, M.M., Khan, R.U., Chand, N., Farooq, U. \& Ahmad, S., 2016. The activity and use of zinc in poultry diet. Wrld's Poult. Sci. J. 72, 159-167.

Onderci, M., Sahin, N., Sahin, K. \& Kilic, N. 2003. Antioxidant properties of chromium and zinc. Biol. Trace. Elem. Res. 92, 139-149.

Rahimi, S. \& Khaksefidi, A., 2006. A comparison between the effects of a probiotic (Bioplus 2B) and an antibiotic (virginiamycin) on the performance of broiler chickens under heat stress condition. Iran. J. Vet. Res. 7, 23-28.

Rouhalamini, S.M., Salarmoini, M. \& Asadi-Karam, Gh., 2014. Effect of zinc sulfate and organic chromium supplementation on the performance, meat quality and immune response of Japanese quails under heat stress conditions. Poult. Sci. J. 2, 165-181.

Sahin, K. \& Kucuk, O., 2003. Zinc supplementation alleviates heat stress in laying Japanese quail. J. Nutr. 133, $2808-2811$.

Samli, H.E., Senkoylu, N., Koc, F., Kanter, M. \& Agma, A., 2007. Effects of Enterococcus faecium and dried whey on broiler performance, gut histomorphology and intestinal microbiota. Arch. Anim. Nutr. 61, 42-49.

Shah, M., Zaneb, H., Masood, S., Khan, R.U., Ashraf, S., Sikandar, A., Faseeh Ur Rehman, H. \& Rehman, H., 2018. Effect of dietary supplementation of zinc and multi-microbe probiotic on growth traits and alteration of intestinal architecture in broiler. Probiotic Antimicrob. Proteins (in press)

Siegel, H., 1995. Stress, strains and resistance. Br. Poult. Sci. 36, 3-22.

Statistical Package for Social Sciences, SPSS for Windows, version 20, SPSS Inc., Chicago, IL, USA

Sultan, A., Ahmad, S., Khan, S., Khan, R.U., Chand N., Tahir, M. \& Ahmad, S., 2018. Comparative effect of zinc oxide and silymarin on growth, nutrient utilization and hematological parameters of heat stressed broiler. Pak. J. Zool. $50,751-756$.

Swain, B., Naik, P., Chakurkar, E. \& Singh, N., 2012. Effect of combined supplementation of probiotic and yeast on growth, carcass characteristics and economics of production in broiler chickens. Anim. Nutr. Feed Technol. 12, $103-110$

Yang, X., Sun, X., Li, C., Wu, X. \& Yao, J., 2011. Effects of copper, iron, zinc, and manganese supplementation in a corn and soybean meal diet on the growth performance, meat quality, and immune responses of broiler chickens. J. Appl. Poult. Res. 20, 263-271.

Zia ur Rahman, Chand, N. \& Khan, R.U., 2017. The effect of vitamin E, L-carnitine and ginger on production traits, immune response and antioxidant status in two broiler strains exposed to chronic heat stress. Environ. Sci. Poll. Res.24, 26851-26857. 